\title{
Histamine-1 Receptor Antagonist
}

National Cancer Institute

\section{Source}

National Cancer Institute. Histamine-1 Receptor Antagonist. NCI Thesaurus. Code C29578.

Any agent that binds to the histamine $\mathrm{H} 1$ receptor, thereby antagonizing histamine mediated allergic reactions, such as bronchoconstriction, vasodilation and up-regulated capillary permeability. 